University of Nebraska - Lincoln

DigitalCommons@University of Nebraska - Lincoln

Mammalogy Papers: University of Nebraska

State Museum

Museum, University of Nebraska State

2009

Historical Winter Diets of Mink (Mustela vison) in Nebraska

Justin D. Hoffman

McNeese State University, jhoffman@mcneese.edu

Sam Wilson

Nebraska Game and Parks Commission

Hugh H. Genoways

University of Nebraska - Lincoln, h.h.genoways@gmail.com

Follow this and additional works at: https://digitalcommons.unl.edu/museummammalogy

Part of the Zoology Commons

Hoffman, Justin D.; Wilson, Sam; and Genoways, Hugh H., "Historical Winter Diets of Mink (Mustela vison) in Nebraska" (2009). Mammalogy Papers: University of Nebraska State Museum. 128.

https://digitalcommons.unl.edu/museummammalogy/128

This Article is brought to you for free and open access by the Museum, University of Nebraska State at DigitalCommons@University of Nebraska - Lincoln. It has been accepted for inclusion in Mammalogy Papers: University of Nebraska State Museum by an authorized administrator of DigitalCommons@University of Nebraska Lincoln. 


\title{
Historical winter diets of mink (Mustela vison) in Nebraska
}

\section{Justin D. Hoffman ${ }^{1}$, Hugh H. Genoways ${ }^{2}$, And SAm Wilson ${ }^{3}$}

\author{
1. Department of Biological Sciences, McNeese State University, Lake Charles, \\ Louisiana - Corresponding author: jhoffman@mcneese.edu \\ 2. School of Natural Resources and University of Nebraska State Museum, Lincoln, \\ Nebraska. \\ 3. Nebraska Game and Parks Commission, Lincoln, Nebraska.
}

\begin{abstract}
Currently there are no published accounts of the specific diets of mink (Mustela vison) in Nebraska. Herein, we present findings of an historic data set on the winter diets of mink in Nebraska. Gastrointestinal (GI) tracts of mink were collected by the Nebraska Game and Parks Commission during the 1946-1947 fur trapping season. The contents of the GI tracts were identified as specifically as possible and percentage of occurrence and percentage of total volume was calculated for each prey item. Mammals and bony fish were the most encountered items. Among mammals, rabbits and muskrats (Ondatra zibethicus) were the most frequently consumed species. The presence of rabbits as a major food source is interesting given that most published reports suggest that rabbits are only opportunistically preyed upon by mink. Other commonly consumed taxa include crayfish and frogs. Our report is consistent with other published accounts in that mink prey on a variety of vertebrate and invertebrate taxa.
\end{abstract}

Keywords: Mustela vison, muskrats, Nebraska, rabbits, winter diet

\section{INTRODUCTION}

Mink are opportunistic carnivores that feed on a wide variety of prey items (Larivière 1999). Because of this, it is expected that mink diets will vary geographically in response to local and regional conditions. Several studies on mink diets have taken place in the Prairie Pothole Region of North Dakota and Canada, where mink prey extensively on the large populations of breeding waterfowl that occur there during the spring and summer (Cowan and Reilly 1973, Eberhardt 1973, Sargeant et al. 1973, Arnold and Fritzell 1987, 1989). Research on mink diets in geographic locations where there are few breeding waterfowl show great amounts of variation in food items (Hamilton 1936, Errington 1943, Sealander 1943, Wilson 1954, Korschgen 1958). Currently there have been no published reports on the specific diets of mink in Nebraska. This type of information is important because wildlife biologists rely on it for making sound management recommendations. The objectives of this study are to report on an historical data set of the winter food habits of mink in Nebraska.

\section{Methodology}

Mink tend to disperse throughout the landscape making collection of population data difficult. A valuable yet underutilized source of information on mink includes those individuals taken by fur harvesters. Fur harvesters present an ideal opportunity for biologists to employ the assistance of the public in gathering valuable natural history data on an important group of mammals. During the 1946 - 1947 trapping season (November 1946 - January 1947) mink trappers were asked by the Nebraska Game and Parks Commission to submit samples of mink gastrointestinal (GI) tracts. Those who agreed were sent a gallon jar, with preservative, tags, and sack cloth to preserve the samples. Although the type of preservative was not 


\begin{tabular}{|c|c|c|}
\hline Prey & $\begin{array}{l}\text { Percentage } \\
\text { of } \\
\text { occurrence }\end{array}$ & $\begin{array}{l}\text { Percentage } \\
\text { of volume }\end{array}$ \\
\hline \multicolumn{3}{|l|}{ Mammals } \\
\hline Unidentified mammal & 12.7 & 8.8 \\
\hline Sylvilagus (floridanus) & 10.2 & 8.4 \\
\hline Ondatra zibethicus & 9.0 & 7.1 \\
\hline Microtus spp. & 4.2 & 7.1 \\
\hline Peromyscus spp. & 0.6 & 0.6 \\
\hline Reithrodontomys spp. & 0.6 & 1.7 \\
\hline Sciurus niger & 0.6 & 0.4 \\
\hline \multicolumn{3}{|l|}{ Birds } \\
\hline Unidentified bird & 4.2 & 2.2 \\
\hline Passeriformes. & 2.4 & 1.8 \\
\hline Phasianus cholchicus & 1.8 & 2.9 \\
\hline Gallus gallus domesticus & 1.8 & 0.2 \\
\hline Anseriformes & 1.8 & 3.0 \\
\hline \multicolumn{3}{|l|}{ Other } \\
\hline Fish (Class Actinopterygii) & 21.1 & 18.0 \\
\hline Crayfish (Infraorder Astacidea) & 10.8 & 5.5 \\
\hline Frog (Order Anura) & 9.0 & 10.4 \\
\hline Insects (Class Insecta) & 3.6 & 0.1 \\
\hline Snake (Order Squamata) & 3.0 & 1.4 \\
\hline
\end{tabular}

specified in the initial report, we suspect that it was a $10 \%$ formaldehyde solution, which was a common preservative at that time (Korschgen 1958). A total of 269 mink stomachs and intestines were collected from local trappers (George Schildman, Nebraska Game and Parks Commission, unpubl. data). We assumed that the samples were identified shortly after collection using all available animal material (bones, hair, feathers), similar to Korschgen (1958); however, this was not made clear in the initial report. Also, there was no discussion of the methods used to separate, dry, and identify the food remains taken from the GI tracts. Most samples were taken from central and eastern Nebraska, primarily east of $100^{\circ}$ longitude. Thirteen of the 269 mink were trapped from a lake or pond, whereas the remainders were taken from river or stream habitats. Mammals and birds were identified as specifically as possible; however, there appears to have been no attempt to identify any of the other major groups beyond a general classification (Table 1). The percent occurrence and percent of total stomach volume were calculated for each prey item.

Percent occurrence represents the relative number of times a prey item was found for the total number of GI tracts that possessed prey remains. The volume of each prey item was estimated and recorded as the percent volume of all stomachs that possessed food items.

\section{Results}

Food remains were identified in 166 (134 stomach and 32 intestine) of 269 GI tracts (Table 1). Of all major groups identified, mammals, and bony fish were the most frequently found items. Among mammals, rabbits and muskrats (Ondatra zibethicus) were the most frequently consumed species, comprising $10.2 \%$ and $9.0 \%$ of the 166 GI tracts, and making up $8.4 \%$ and $7.1 \%$ of the total volume, respectively. We assumed eastern cottontails (Sylivilagus floridanus) constituted the majority of rabbit prey because most mink were trapped in the central and eastern portions of the state, which falls almost entirely within the range of the eastern cottontail, as well as, outside the range of the other cottontail species, the desert cottontail (Sylivilagus audubonii), in Nebraska (Jones et al. 1983). The presence of rabbits as a common food item for mink is a bit surprising. Most studies indicate that rabbits are only opportunistically preyed upon by mink (Cowan and Reilly 1973, Arnold and Fritzell 1987, Larivière 1999), although some exceptions exist (Korschgen 1958). Voles (Microtus spp.) occurred in only $4.2 \%$ of the 166 GI tracts, but made up $7.1 \%$ of the total volume. Bony fish prey made up $21.1 \%$ of the 166 GI tracts and $18 \%$ of the total volume. Frogs and crayfish occurred commonly, comprising $10.4 \%$ and $5.5 \%$ of the total volume, respectively. Native and domestic birds made up $10.1 \%$ of the total volume. Other items found included snakes and insects. The breadth of food items reported here concurs with other studies of mink diets (Errington 1943, Korschgen 1958, Jones et al. 1983). 


\section{Discussion}

We were especially interested in the abundance of muskrat as a food source for mink. Muskrats are one of the most commonly taken furbearer species in Nebraska (Landholt and Genoways 2000) and are common prey items of mink (Errington 1943). Many factors can influence mink predation on muskrats including water levels, abundance of prey, and season. Proulx et al. (1987) found that when water levels were low, mink would venture into the interiors of marshes and prey on waterfowl and muskrats. However, when water levels were high, mink tended to remain on the periphery of the marshes and feed primarily on voles and crayfish. Errington $(1954,1961)$ similarly reported that mink seldom traverse into the deep portions of marshes until the water froze or during drought conditions. Finally, in some areas, mink predation on muskrats tends to be higher during the fall and winter seasons (Yeager 1943, Wilson 1954; but see Hamilton 1936, 1940), possibly due to the freezing of water resulting in greater access to muskrat populations (Errington 1954, 1961).

Because our Nebraska data were collected approximately 62 years ago, it is difficult to determine how the above ecological factors affected mink predation on muskrats at that time. For instance, there are some indications that muskrat populations were low during the sample period. Sather (1958) reported that approximately 190,000 muskrat pelts were harvested during the 1946 - 1947 season compared to 275,000 harvested during the 1945 - 1946 season. Further, 95\% of the mink used in this study were taken from a river or stream habitat; whereas, muskrat populations tend to be highest in shallow lakes, ponds, and wetlands (Jones et al. 1983). This sampling bias towards river and stream habitats could have underestimated the overall importance of muskrats as a prey item to mink. Finally, there is not sufficient information on water levels during the 1946 - 1947 season to be able to draw any conclusions on mink diets as they relate to water levels.

\section{Conclusion}

We found that mink in eastern and central Nebraska commonly feed upon species from most major vertebrate taxa as well as various invertebrate taxa. Some of the more important food items for mink in Nebraska included rabbits, muskrats, fish, crayfish, and frogs. Our results represent one of the few reported cases where rabbits are frequently preyed upon by mink. Finally, the occurrence of muskrat in mink diet could not be fully assessed due the lack of information regarding important ecological factors such as muskrat density, water levels, and sampling bias.

\section{Literature Cited}

Arnold, T.W. and Fritzell, E.K. 1987. Food habits of prairie mink during the waterfowl breeding season. Canadian Journal of Zoology 65:2322-2324.

Arnold, T.W. and Fritzell, E.K. 1989. Spring and summer prey remains collected from male mink dens in southwestern Manitoba. Prairie Naturalist 21:189-192.

Ben-David, M., Hanley, T.A., Klein, D.R. and Schell, B.M. 1997. Seasonal changes in diets of coastal and riverine mink: the role of spawning Pacific salmon. Canadian Journal of Zoology 75:803-811.

Cowan, W.F. and Reilly, J.R. 1973. Summer and fall foods of mink on the J. Clark Salyer National Wildlife Refuge. Prairie Naturalist 5:20-24.

Eberhardt, R.T. 1973. Some aspects of minkwaterfowl relationships on prairie wetlands. Prairie Naturalist 5:17-19.

Errington, P.L. 1943. An analysis of mink predation upon muskrats in north-central United States. Iowa Agricultural Experiment Station Research Bulletin 320:797-924.

Errington, P.L. 1954. The special responsiveness of minks to epizootics in muskrat populations. Ecological Monographs 24:377-393. 
Errington, P.L. 1961. Muskrats and marsh management. Wildlife Management Institute Publication. University of Nebraska Press, $183 \mathrm{pp}$.

Hamilton, W.J., Jr. 1936. Food habits of the mink in New York. Journal of Mammalogy 17:169.

Hamilton, W.J., Jr. 1940. The summer foods of mink and raccoons on the Montezuma Marsh, New York. Journal of Wildlife Management 4:80-84.

Jones, J.K., Jr., Armstrong. D.M., Hoffmann, R.S. and Jones, C. 1983. Mammals of the northern Great Plains. University of Nebraska Press, Lincoln, Nebraska, 379 pp.

Korschgen, L.J. 1958. December food habits of mink in Missouri. Journal of Mammalogy 39:521-527.

Landholt, L.M. and Genoways, H.H. 2000.

Population trends in furbearers in Nebraska. Transactions of the Nebraska Academy of Sciences 26:97-110.

Larivière, S. 1999. Mustela vison. Mammalian Species 608:1-9.
Proulx, G., McDonnell, J.A. and Gilbert, F.F. 1987. The effect of water level fluctuations on muskrat, Ondatra zibethicus, predation by mink, Mustela vison. The Canadian Field-Naturalist 101:89-92.

Sargeant, A.B., Swanson, G.A. and Doty, H.A. 1973. Selective predation by mink, Mustela vison, on waterfowl. American Midland Naturalist 89:208-214.

Sather, J.H. 1958. Biology of the Great Plains muskrat in Nebraska. Wildlife Monographs 2:1-35.

Sealander, J.A. 1943. Winter food habits of mink in southern Michigan. Journal of Wildlife Management 7:411-417.

Wilson, K.A. 1954. The role of mink and otter as muskrat predators in northeastern North Carolina. Journal of Wildlife Management 18:199-207.

Yeager, L.E. 1943. Storing muskrats and other foods by mink. Journal of Mammalogy 24:100-101. 